\title{
United Nations Initiatives For Promoting Of Women Empowerment: Historical Perspective
}

\author{
Muhammad Ali \\ Department of Political Science \\ University of Karachi \\ Muhammad Nadeemullah \\ Department of Social Work \\ University of Karachi \\ Fauzia Ghani \\ Department of Political Science \\ Government College University, Lahore
}

\begin{abstract}
The present study "United Nations Initiatives for Promoting of Women Empowerment: A Historical Perspective" is aimed at determining the role of UNO in protecting women rights. Women are discriminated at various levels in different societies and subjected to violence both physical and mental. The impacts go beyond the family and affect not only the victim but the society as whole. Securing the legal foundations of gender equality and women empowerment has always remained one of the main tasks of the United Nation Organization (UNO). The charter of UNO specifically emphasize on the equal fundamental freedom of men and women. It clearly guarantees the fundamental rights to all without distinction of race, colour, gender or any other status. The objective of this research paper is to provide historical background of global initiatives, particularly in the frame work of the UNO, regarding the process of women's empowerment and gender equality. It also highlights the major challenges and hurdles in this perspective.
\end{abstract}

Key Words: Women Empowerment, United Nations, Discrimination, History, Initiatives and Effects

\section{ثلخيص}

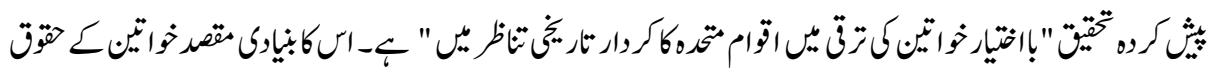

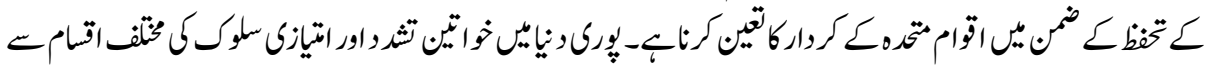

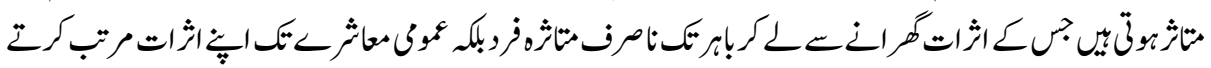

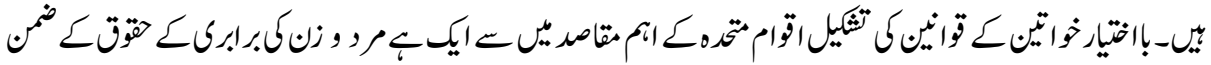

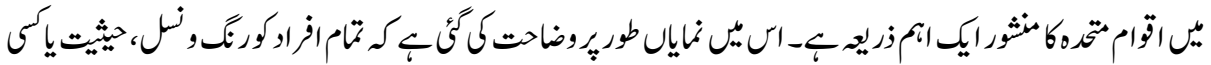

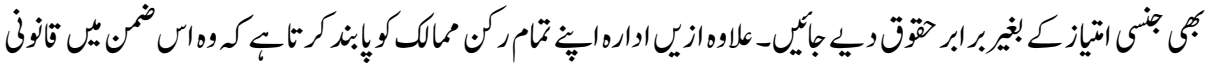

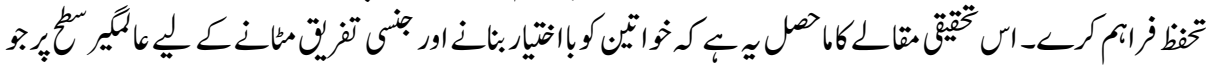




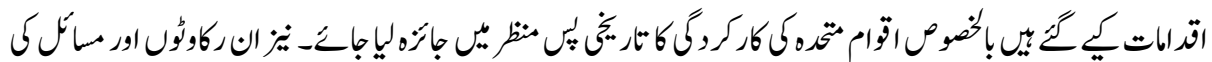

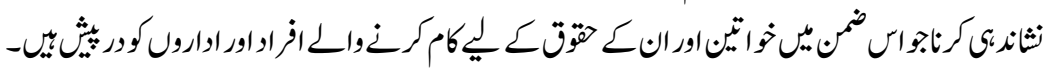

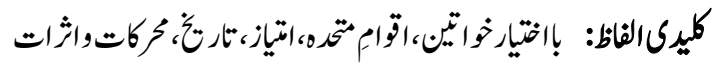

\section{Introduction}

In the modern world, human rights idea is universally accepted by virtually all states and societies regardless of historical, cultural, ideological, economic or other differences. It is philosophically respectable, even to oppose philosophical persuasions. The universalization of human right is a political fact international. Women rights are those rights which are concerned to women and girls which protect them from violation. Women rights are the entitlements claimed for women and girls of many societies worldwide. In some places these rights are institutionalized or supported by law, local custom and behaviour, whereas in other they may be suppressed. These rights in some societies are protected through law and customs but in some places these are violated and ignored from last six decades. Women empowerment and promotion of gender equality are one of the main ideologies of UNO (Ghosh, 2009: 246). To promote women rights is not only a goal of an organization. It is actually the common goal of different people and organization who have been working for so many decades. There are about $95 \%$ of the participants in the movement were organized under the umbrella of UNO. (Wittkopf. 2004; 250) In order to analyze the origins of the problem, it is essential to also understand the generic historical background of feminist movements in a holistic manner under the umbrella of UNO.

\section{Research Problem of the Study}

The research problem behind the study is to examine that whether the UNO is/was really effective decision maker in global efforts for advancement of women? Specifically, the research mainly revolves around the assumption that how the UNO initiatives can help in promoting the women empowerment process. Apart from the above research problem, the main objectives of this study are stated as following:

- To provide historical background of the global efforts in the way of women empowerment.

- To examine the UNO's initiatives for advancement of women since from post Second World War era.

- To highlight UN policy on Violations against the Women and gender discrimination,

- To find out those major hurdles which are responsible for this process?

\section{Research Methodology}

The study is planned as a qualitative method and based on available literature review on 
the research problem. Keeping in view the nature of research objectives, the efforts have been made to collect material from diverse sources. Thus there is a combination of primary and secondary sources. Information has been collected and shifted from documents such as the UNO treaties, books, journals, speeches, statements and official declarations and communications. Interaction with other scholars by attending international seminars, conferences and workshops, has been very useful in developing clarity in thinking about various aspect of the topic.

\section{Significance of the Study}

On the basis of reviewed literature, this theoretical research paper is organized in four sections. First part deals with objectives, methodology and research problem of the study. Second part focuses on the brief but comprehensive back ground of research problem. The third part deals with the UNO policy toward women rights violations under the different treaties and conventions. A summary of findings, recommendations and some predictions for the research problems would be discusses in the last section of the study. It is expected that the results of this work would not only facilitate the scholars and experts of gender politics and women rights activism but it would be also a massive contribution for the students, women rights activism and policymakers in the field of gender studies.

\section{Back ground of the Research Problem}

After the end of World War I which lasted from 1914 to 1918, The League of Nations (LN) was formed in 1919. Its mission was to maintain world peace. In the interregnum between the two world wars, the International Labour Organization (ILO) drafted and adopted two conventions on maternity protection (1919) and on the limitation on employment of women in night shifts (revised in 1934. In 1935, the Assembly of the League of Nations resolved to examine the legal and social conditions of women in the matter of civil and political rights. These efforts for women empowerment were discontinued during the World War II (1939-1945) and later resumed by the UNO. (Subramanian; 2004, 173) After the end of WW II, the UNO was founded, by 51 countries, on October 24, 1945 to replace the flawed League of Nations. Its principal mission is to maintain world peace, to develop friendly relations among nations and promoting social progress and better living conditions, to increase respect for human rights and to provide a platform for dialogue.( Ghosh,2009 : 245)The Organization works on a wide range of key international issues like sustainable development, environment, the protection of refugees ,disaster relief, counter-terrorism, disarmament and non-proliferation, the promotion of democracy and human rights, good governance for a safer world for this and future generations. (SeeUNO at Glance)To achieve these objectives, the Charter of the organization provides the following principal organs and bodies for implementing 
the policies of UNO. The General Assembly brings together member states at the highest level (Heads of State or Government), along with Secretary General, and meet generally once in a year mostly in September. In actual fact, it has become the practice to convene it once in every year. The Security Council has clearly emerged as the highest decision making institutional forum of the UNO in the realm of international security cooperation. It consist of I5 members, including United States, United Kingdom, Russia France and China as permanent while 10 as non-permanent member states. Economic and Social Council (ECOSOC) consist of fifty four member states, elected by three year term. The mandate of ECOSOC is to assist UN General Assembly in the promotion of global socio-economic development, cooperation and human rights. The Secretariat is the highest executive body of the UNO. As the organization's highest administrative body, it is responsible for initiating legislative proposal, implementing policies and decisions and running the organization on a daily basis. It is located in New York. The Secretariat comprises the Secretary- General. He is appointed for a term of five years, although this may be increased in special circumstances. He is assisted by the Professional and the General Services Staff (Ghosh, 2009: 247).

\section{Women Rights under the UNO}

The UN Charter was signed by 51 countries on 26 June and entered into force on 24 October 1945. The charter set forth the principles, objectives and institutional arrangements of the organization. Originally charter consisting with one preamble and 111 Articles (Wittkopf. 2004; 250). The various protocol and the declarations have been adopted by the member states time to time. Securing the legal foundations of gender equality is always remaining one of the main tasks of the UNO. Since its inception, its support for the rights of women began with the Preamble of the Organization's founding Charter, which sets as one of the central goals the reaffirmation of "faith in fundamental human rights, in the dignity and worth of the human person, in equal right of men and women". The purpose of the UN include international cooperation "in promoting and encouraging respect for human rights and for fundamental freedom for all without distinction as to race, sex, language or religion"(Article 1 of the charter). The charter of UNO was the first international mechanism which specifically refer to the gender equality and legally bound to all its member countries to struggle for the equal fundamental freedoms of men and women (Devaki, $2005: 19-20$ ).

Women right are the responsibilities for study and recommendation of the UN General Assembly (Article 13) and Economic and Social Council (Article 62(2) and Commission on Human Rights is expressly required (Article 68). The various UN bodies have devoted years of arduous efforts to promoting women rights. Among the other organs of the UNO primarily concerned with the promotion of women rights and gender equality, the Commission on the Status of Women (CSW), was established by resolution in 11(II) of 21 June 1946 under the supervision of Economic and Social Council (ECOSOC). Originally it was a sub commission of Human Rights, but due to severe pressure by feminist activists 
and civil society organization at that time it was rapidly granted the status of full commission (ECOSOC). It is the principal global policy-making body dedicated exclusively to gender equality and advancement of women. The Commission makes recommendations to the Council on urgent problems requiring immediate attention in the field of women's rights. Every year, Member States evaluate progress on gender equality, identify challenges, set global standards and formulate concrete policies to promote gender equality and women's empowerment worldwide (See Advancement of Women). The CSW and other organs of the UN system sought to encourage and to assist governments to give women equal opportunities as well as equal rights with men. Interested organs and agencies within the UN system used and exploited all the methods and techniques available , including technical assistance, to enable women to participate in all aspects of national and international life and to encourage their participation (Subramanian;2004 :173-174). During the 1946-1962, the CSW plays a significant role under the supervision of ECOSO and frame work of UNO. It started coordinating with internationally human right bodies. The CSW played a significant contribution in the drafting of the Universal Declaration of Human Rights (UDHR). In its first international task, members of CSW introduced gendersensitive language - arguing against references to "men" as a synonym for humanity and phrases like "men are brothers." Despites the severe resistance from human rights commission, the CSW succeeded in introducing new, more comprehensive language for the women. It was a great breakthrough in a historical perspective of gender equality (Devaki, 2005: 19-20). The land mark Declaration UDHR endorses that "All human beings are born free and equal in dignity and rights" and that "everyone is entitled to all the rights and freedoms set forth in this Declaration, without distinction of any kind, such as race, colour, sex, language, religion, birth or other status. The UDHR emphasize all of its member states to encourage and support the social, civil and economic freedom of women.

During the fifties and sixties, the CSW played a significant role under the supervision of ECOSO and frame work of UNO. It expounded various conventions/treaties - the Convention on the Political Rights of Women (1952), the Nationality of Married Women (1957), Convention on Minimum Age for Marriage, Consent to Marriage and Registration of (1962)- to protect and promoted those areas of women rights which the UNO considered such rights to be mainly susceptible. All these Conventions were adopted by UN General Assembly to protect women and for gender equality. In addition, in 1966 women were given more powers in the International Covenant on Civil and Political Rights (ICCPR) and the International Covenant on Economic, Social and Cultural Rights (ICESCR).Both of these Covenants specially bind the ratifying member countries to ensure that gender equality should be established. On the request of the UNGA in 1963, the CWS started to prepare a working draft for elimination of any type of discrimination of women. Women's rights activists fully supported the drafting process. The final Declaration on the Elimination of Discrimination against Women (DEDAW) was presented before the UNGA, and eventually accepted on 7 November 1967.Like the structure of UDHR the Declaration was consist with a preamble and eleven articles . Most importantly article six related to equality in marriage and the family, and article ten concerning to Employment. Despite DEDAW was significant landmark of CWS in securing the legal foundation of gender equality and women empowerment but its impact 
was very low. Due to voluntary implementation, the level of response of member states was not up to mark.

In 1970, on the recommendation of the commission and UN General Assembly adopted a program of concerted international action for the advancement of women .The program set forth general objectives and minimum targets to be achieved during the second United Nations Development Decade (1971-1980). At the suggestion of CSW and number of nongovernmental organizations, the UN General Assembly proclaim " 1975 " as the international year of women in 1972. The CSW organized the first World Conference on Women, held in Mexico City from June 19 to July 2. The Conference consequently declared the years 1976-1985 as the UN Decade for Women, and established a Voluntary Fund for Decade (Wittkopf . 2004; 251). In 1976, UN General Assembly adopted criteria for use of the voluntary fund and proposal for its management. The criteria stress that in utilizing the fund resources, priorities should be given to project benefiting rural women, poor women in the urban areas and similar disadvantage groups(Subramanian ;2004 ,175-176).

In resolution no '34/180, the General Assembly adopted the Convention on the Elimination of All Forms of Discrimination against Women (CEDAW), in 1979 ,by votes of 130 to none, with 10 abstentions. It entered into force on 3 September 1981; just 30 days after the twentieth state had ratified it - faster than any previous human rights convention (Devaki, 2005: 21-22). The Convention is consisting with thirty articles and a preamble. In defining discrimination against women the convention explicitly recognizes that widespread discrimination against women continues to exist. The convention emphasizes that such discrimination "violates the principles of equality of rights and respect for human dignity"(See Preamble of CEDAW).The CEDAW gives positive affirmation to the principle of equality by requiring states /parties to take "all appropriate measures, including legislation, to ensure the full development and advancement of women, for the purpose of guaranteeing them the exercise and enjoyment of human rights and fundamental freedoms on a basis of equality with men"(article 3). Despite, special protection for maternity, forced prostitution and women trafficking are not regarded as gender discrimination (Article 4), however, it is often describe as an international bill of rights for women. To ensure, the provisions of CEDAW were followed by signatory countries, a committee (CEDAW) was established in 1981 under the article 17 of the convention. The Committee's mandate is very specific: it watches over the progress for women empowerment, monitors the implementation of national measures to fulfill this obligation (Committee of CEDAW). Although committee was initially not authorized to receive individual communication, but this has changed in 1993 when it was authorized to examine individual petition for any kind of Violence Again Women. (Hamelink,2004:79)

\section{From CEDAW to DEVAW (1993): Putting Women on the Global Agenda}

The issue of the advancement of women's rights has concerned the United Nation since the organization 'founding. Yet the alarming global dimension of female targeted violence was not explicitly acknowledged by the international community until the December 1993 when the United Nation General Assembly adopted the Declaration on the Elimination of Violence Against Women (DEVAW). The DEVAW as adopted by the 
General Assembly on 20 December 1993. As a result of these steps the problem of violence against women has been drawing increasing political attention. Until that point, most governments tended to regard violence against women largely as a private matter between individual, and not as a pervasive human right problem requiring state intervention. The DEVAW is the first international human rights instrument to exclusive and explicitly address the issue of violence against women. It affirms that the phenomenon violates, impairs or nullifies women's human rights and their exercise of fundamental freedoms. This landmark document was a result of collective efforts of UN's Organs -ECOSOC, CWS, UN Women and global feminist women to address the violence against women (Wittkopf. 2004; 252).

Another landmark (OP-CEDAW) legal document was adopted by UN General Assembly on 6 October 1999, and in force from 22 December 2000, which introduced the right of petition for women victims of discrimination. It also establishes a complaint and inquiry mechanisms for the (CEDAW). At present, OP-CEDAWhas been signed by 80 countries. It is important to mention here that the OP-CEDAW is a secondary arrangement to the CEDAW, which does not create any further women right, but rather allows the rights guaranteed in the Convention to be enforced. To promote the further progress toward advancement and empowerment of the women UN General Assembly established a UN Women in July 2010. It was another historical landmark by the UN member counties. The establishment of UN Women came about as part of the UN reform agenda which exclusively focus on gender equality and women empowerment. The UN Women perform the following functions under the framework of UN;

- To coordinate in policy formulation with UNO'S institutions and intergovernmental bodies

- To provide the technical and financial support to its member countries to forge effective partnerships with civil society.

- To hold the UN system accountable for its own commitments on gender equality, including regular monitoring of system-wide progress.( UN Women )

The CSW agreed on a draft, in 2014 that called for the acceleration of progress towards achieving the UN's millennium development goals. The document established the need for a stand-alone goal on women's empowerment and gender equality in post-2015 goals.

\section{Pakistan and Women Empowerment}

Being a member of UNO and its subvention organs, Pakistan fully committed on gender equality and women's empowerment not only as human rights, but also because they are a pathway to achieving the Millennium Development Goals and sustainable development. Women's empowerment has been a major theme in Pakistan's national development policies ever since the inception of the country. The Constitution of Pakistan guarantees 
non-discrimination against women and advocates full participation of women in all spheres of national life. (Article 25, 26 and 27 and 32 of Pakistan) ${ }^{1}$ However, in a patriarchal society like Pakistan, women empowerment is also very difficult to achieve as societies and communities are governed by strictly social and cultural norms. There is very worse situation has been reported for Pakistan in term of gender inequality and women empowerment. According to MDG Report (2013), Pakistan is still far away from the targets of 2015 in terms of access of education, gender equality and women empowerment which is reflected by child mortality, maternal health and nutrition (Government of Pakistan 2013). The Pakistan ranks 121 as overall on the Gender Gap Index 2014 out of 142 counties, and the rank of Pakistan on Human Development Index is 146 out of 187 countries in 2014, Furthermore the rank of Pakistan was 141 for economic participation and opportunity for women, for education attainment Pakistan rank was 132, in term of health and survival 119 and 85 in term of political empowerment in 2014.Being a signatory of CEDAW, Pakistan is legally bound to implement the treaty in latter and spirit. It is about time for the government, civil society and pressure groups to strive to eliminate all form of discriminatory practices against women.

\section{Conclusions}

Throughout its sixty years of existence and its fifty sessions, the UNO has consistently promoted the advancement of women. It has been instrumental in expanding the recognition of women's rights, in documenting the reality of women's lives throughout the world, in shaping global policies on gender equality and empowerment of women and in ensuring that the work of the organization is all areas incorporates a gender perspective. It continues to play a critical role by bringing together Governments, UN entities, NGOs, and other international and regional organizations to promote women's rights and advance gender equality. All of its intuitions having mandate of women rights especially CSW has played a vital role within the United Nations system and under the supervision of ECOSO and UNGA to achieve the above mentions objective. The Commission ensured that provisions for equality between women and men were included in the UDHR - a landmark in the struggle for equality. The Convention has been an inspiration for women in all parts of the world. It has had a positive impact on legal and policy development at national level, for example through the strengthening of provisions in constitutions, the establishment of commissions to review legislation, and the development of temporary special measures to enhance women's participation in different areas.

\section{Recommendations}

The post-2015 global development agenda offers a real opportunity to drive lasting change for women's rights, equality and empowerment. To make greater progress, it is widely believe that international community should take the urgent action on the following areas: 
- End the all type of violence against the girl and women

- Discrimination of all forms must be end.

- UN women should be given more mandates.

- Voice of women should be heard.

- Equal opportunities, resources and responsibilities must be provided to realize equality.

- Effective media campaign for women 's education

- The civil society organizations (CSO), including NGOs and independent media and the private sector, which compose the main structure of the vertical model, should be more articulated.

In conclusion, the role of the women nowadays is very important because somehow all the society needs to know how is the role of the women through the different cultures in the world. Women's rights have become better, but there are still some issues. I think women should have a voice to talk about their problems. That is the major way to solve the problems. In addition, women should go to areas of high position in politics, business, and education.It is time for women to participate equally in decision making in the household, the private sector and institutions of governance.

\section{Time Line}

UNO Initiatives for Promoting of Women Empowerment

\begin{tabular}{|l|c|}
\hline Treaties/ conventions/Conferences & Year \\
\hline Charter of UNO & 1945 \\
\hline Universal Declaration of Human Rights(UDHR) & 1948 \\
\hline The Convention on the Political Rights of Women & 1952 \\
\hline The Convention Nationality of Married Women & 1957 \\
\hline The Convention on Minimum Age for Marriage & 1962 \\
\hline The Convention Consent to Marriage and Registration of & 1962 \\
\hline The International Covenant on Civil and Political Rights (ICCPR) & 1966 \\
\hline $\begin{array}{l}\text { The International Covenant on Economic, Social and Cultural Rights } \\
\text { (ICESCR) }\end{array}$ & 1966 \\
\hline $\begin{array}{l}\text { The Declaration on the Elimination of Discrimination against } \\
\text { Women(DEDAW) }\end{array}$ & 1967 \\
\hline The UN Decade for Women & $1976-1985$ \\
\hline The Elimination of All Forms of Discrimination Against Women (CEDAW), & 1979 \\
\hline The Declaration on The Elimination of Violence Against Women (DEVAW) & 1993 \\
\hline Optional Protocol to CEDAW (OP-CEDAW) & 2000 \\
\hline UN Women & 2010 \\
\hline Post-2015 Global Development Agenda & \\
\hline
\end{tabular}




\section{End Notes}

1. Article 25, 26 and 27 and 32 of constitution of Pakistan 1973, All citizens are equal before law and are entitled to equal protection of law There shall be no discrimination on the basis of sex.

\section{References}

Advancement of Women http://www.un.org/en/development/progareas/women.shtml, accessed on 24-8 -2014

Declaration on the Elimination of Discrimination against Women

Declaration on the Elimination of Violence against Women http://www.un.org/ womenwatch/daw/CSW60YRS/\#MAJOR Accessed on 26-8 -2014

Devaki JAIN. (2005). Women, Development and the UN: A Sixty-year Quest for Equality and Justice, Bloomington, Indiana Press University, pp. 19-20.

ECOSOC Resolution establishing the Commission on the Status of Women. E/RES/2/11, 21 June 1946

Human Development Report (2014) http://hdr.undp.org/sites/default/files/hdr14-reporten-1.pdf

Ghosh, Peu (2009). International Relation ,Phi Learning Private Limited New Delhi

http://www.un.org/womenwatch/daw/cedaw/Accessed on 25-8 -2014

Subramanian. S, (2004). Human Rights International Challenge, Manas Publication, New Delhi.

The United Nations Commission on the Status of Womenwww.un.org/womenwatch/ daw/CSW60YRS/Accessed on 15-8 -2014

Trivedi Sonu, (2005). A Hand Book Of International Organization, Atlantic publisher London.

Turner Barry, (2008). The State Man Year Book 2008, the Politics Culture and Economics, Palgrave, London. 
UN Women www.unwomen.org/Accessed on 24-7-2014

United Nations High Commissioner for Human Rights (OHCHR) http://www.ohchr. org/en/ProfessionalInterest/pages/cedaw.aspxAccessed on 14-6-2014

Universal Declaration of Human Rights (UDHR) http://www.un.org/en/documents/udhr/ Accessed on 25-11 -2014

UNO Official web site http://www.un.org/en. Accessed on 14-5-2014

UNO (2014) Europa Regional Survey of the World, Routledge, London.

Uno at Glance:http://www.un.org/en/aboutun/

Wittkopf.R Eugene (2004) World Politics Trend and Transformation, Thomas Publisher, Canada

Dr. Muhammad Ali is Assistant Professor in the Department of Political Science, University of Karachi.

Dr. Muhammad Nadeemullah is Assistant Professor in the Department of Social Work, University of Karachi.

Fauzia Ghani is Assistant Professor in the Department of Political Science, Government College University, Lahore. 